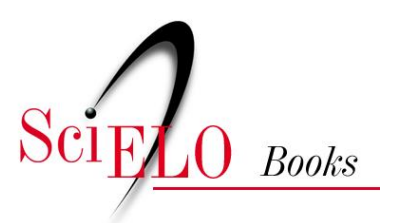

กำ

FIOCRUZ

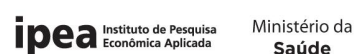

Secretaria de

Assuntos Estratégicos

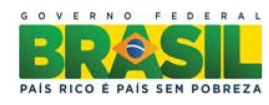

\title{
Desenvolvimento como eixo e os eixos para desenvolvimento
}

\author{
Inessa Laura Salomão \\ José Celso Pereira Cardoso Jr. \\ José Carlos dos Santos
}

\section{SciELO Books / SciELO Livros / SciELO Libros}

SALOMÃO, IL., CARDOSO JR., JCP., and SANTOS, JC. Desenvolvimento como eixo e os eixos para desenvolvimento. In FUNDAÇÃO OSWALDO CRUZ. A saúde no Brasil em 2030 - prospecção estratégica do sistema de saúde brasileiro: desenvolvimento, Estado e políticas de saúde [online]. Rio de Janeiro: Fiocruz/Ipea/Ministério da Saúde/Secretaria de Assuntos Estratégicos da Presidência da República, 2013. Vol. 1. pp. 63-100. ISBN 978-85-8110-015-9. Available from SciELO Books <http://books.scielo.org>.

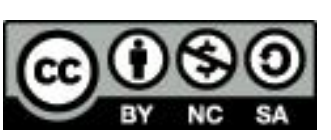

All the contents of this chapter, except where otherwise noted, is licensed under a Creative Commons Attribution-Non Commercial-ShareAlike 3.0 Unported.

Todo o conteúdo deste capítulo, exceto quando houver ressalva, é publicado sob a licença Creative Commons Atribuição Uso Não Comercial - Partilha nos Mesmos Termos 3.0 Não adaptada.

Todo el contenido de este capítulo, excepto donde se indique lo contrario, está bajo licencia de la licencia Creative Commons Reconocimento-NoComercial-CompartirIgual 3.0 Unported. 


\section{Desenvolvimento como Eixo e os Eixos para Desenvolvimento}




\title{
DESENVOLVIMENTO COMO EIXO E OS EIXOS PARA O DESENVOLVIMENTO ${ }^{1}$
}

\author{
Inessa Laura Salomão \\ José Celso Pereira Cardoso Jr. \\ José Carlos dos Santos
}

\section{1 | CONTEXTUALIZANDO O DEBATE EM CURSO²}

Em tempos como os que estamos vivendo, de largo predomínio das ideias de uma mundialização sem fronteiras da economia (sobretudo a financeira) e de um crescente questionamento em relação à operatividade (em termos da efetividade e eficácia) dos sistemas democráticos de representação, torna-se crucial voltar a discutir o tema da natureza, alcances e limites do Estado, do planejamento e das políticas públicas no capitalismo brasileiro contemporâneo.

Este tema se torna particularmente relevante agora, uma vez passada a avalanche neoliberal das décadas de 1980 e 1990 e suas crenças em torno de uma concepção minimalista de Estado. Diante do malogro do projeto macroeconômico neoliberal (baixas e instáveis taxas de crescimento) e suas consequências negativas nos planos social e político (aumento das desigualdades e da pobreza, e o enfraquecimento dos mecanismos democráticos), evidencia-se já na primeira década do novo século certa mudança de opinião a respeito das novas atribuições dos Estados Nacionais.

O contexto atual de crescente insegurança internacional (terrorismos, fundamentalismos, guerras preventivas etc.) e de grande incerteza econômica no sentido keynesiano forte tem ensejado, nos círculos conservadores da mídia e da intelectualidade dominante, bem como nas agências supranacionais (Fundo Monetário Internacional, Banco Interamericano de Desenvolvimento, Banco Mundial, Organização Mundial do Comércio etc.), um discurso menos hostil às ações dos Estados Nacionais nos seus

1 As opiniões aqui emitidas são de inteira responsabilidade dos autores, não expressando, necessariamente, a visão oficial do órgão.

2 Esta introdução é uma versão ligeiramente modificada da Introdução escrita para o livro Desafios ao Desenvolvimento Brasileiro: contribuições do conselho de orientação do Ipea, organizado por J. Celso Cardoso Jr., IPEA, 2009. 
respectivos espaços territoriais. Tal discurso se mostra favorável a maior controle sobre a segurança interna, mas também sobre seus sistemas econômicos e sociais. Embora a ênfase das políticas domésticas ainda esteja centrada na harmonização e homogeneização das estruturas de produção e distribuição, nos controles orçamentários e na inflação, começa a haver certo espaço para ações mais abrangentes e ativas dos Estados visando tanto a recuperação do crescimento econômico como o combate à degradação das condições de vida, ações estas que dizem respeito à viabilidade e sustentabilidade dos sistemas ambientais, de produção e de proteção social em geral.

Estas questões recolocam - necessariamente - o tema do Estado no centro da discussão sobre os rumos do desenvolvimento, em sua dupla perspectiva, global-nacional. Por mais que as economias nacionais estejam internacionalizadas do ponto de vista das possibilidades de valorização dos capitais individuais e do ponto de vista do crescimento nacional ou regional agregado, parece evidente, hoje em dia, que ainda restam dimensões consideráveis da vida social sob custódia das políticas nacionais, o que afiança a ideia de que os Estados Nacionais são ainda os principais responsáveis pela regulação da vida social, econômica e política em seus espaços fronteiriços. O tempo das crenças ingênuas em favor das teses ligadas à irrelevância da atuação estatal em geral parece estar chegando ao fim.

Com isso, recupera-se nas agendas nacionais a visão de que o Estado é parte constituinte (em outras palavras: não exógeno) do sistema social e econômico das nações, sendo - em contextos históricos tais quais o do Brasil - particularmente decisivo na formulação e condução de estratégias virtuosas de desenvolvimento. Desenvolvimento, por sua vez, entendido em inúmeras e complexas dimensões, todas elas socialmente determinadas, portanto mutáveis com o tempo, os costumes e as necessidades dos povos e regiões do planeta.

Ademais, o desenvolvimento de que aqui se fala tampouco é fruto de mecanismos automáticos ou determinísticos, de modo que, na ausência de indução minimamente coordenada e planejada (e reconhecidamente não totalizante), muito dificilmente um país conseguirá combinar — satisfatória e simultaneamente — aquelas inúmeras e complexas dimensões do desenvolvimento. Mas que dimensões são estas?

Ao longo do processo de planejamento estratégico — iniciado em 2008 e tendo suas matrizes revisadas em 2011, ainda em curso no IPEA - identificaram-se sete grandes dimensões ou eixos estruturantes para o desenvolvimento brasileiro, quais sejam: 1) inserção internacional soberana; 2) macroeconomia para o pleno emprego; 3) infraestrutura econômica, social e urbana; 4) estrutura tecnoprodutiva avançada e regionalmente articulada; 5) sustentabilidade ambiental; 6) proteção social, garantia de direitos e geração de oportunidades; 7) fortalecimento do Estado, das instituições e da democracia. 
O conjunto de documentos derivados do projeto Perspectivas do Desenvolvimento Brasileiro, até o momento, é o seguinte:

a) Livro 1 - Desafios ao Desenvolvimento Brasileiro: Contribuições do Conselho de Orientação do Ipea - publicado em 2009.

b) Livro 2 - Trajetórias Recentes de Desenvolvimento: Estudos de Experiências Internacionais Selecionadas — publicado em 2009.

c) Livro 3 - Eixo Inserção Internacional Brasileira Soberana:

- Volume 1 - Inserção Internacional Brasileira: Temas de Política Internacional.

- Volume 2 - Inserção Internacional Brasileira: Temas de Economia Internacional.

d) Livro 4 - Eixo Macroeconomia para o Desenvolvimento:

- Volume único - Macroeconomia para o Desenvolvimento: Crescimento, Estabilidade e Emprego.

e) Livro 5 - Eixo Estrutura Produtiva e Tecnológica Avançada e Regionalmente Integrada:

- Volume 1 - Estrutura Produtiva Avançada e Regionalmente Integrada: Desafios do Desenvolvimento Produtivo Brasileiro.

- Volume 2 - Estrutura Produtiva Avançada e Regionalmente Integrada: Diagnóstico e Políticas de Redução das Desigualdades Regionais.

f) Livro 6 - Eixo Infraestrutura Econômica, Social e Urbana:

- Volume 1 - Infraestrutura Econômica no Brasil: Diagnósticos e Perspectivas para 2025.

- Volume 2 - Infraestrutura Social e Urbana no Brasil: Subsídios para uma Agenda de Pesquisa e Formulação de Políticas Públicas.

g) Livro 7 - Eixo Sustentabilidade Ambiental:

- Volume único - Sustentabilidade Ambiental no Brasil: Biodiversidade, Economia e Bem-Estar Humano.

h) Livro 8 - Eixo Proteção Social, Garantia de Direitos e Geração de Oportunidades:

- Volume único - Perspectivas da Política Social no Brasil. 
i) Livro 9 - Eixo Fortalecimento do Estado, das Instituições e da Democracia:

- Volume 1 - Estado, Instituições e República.

- Volume 2 - Estado, Instituições e Democracia.

- Volume 3 - Estado, Instituições e Desenvolvimento.

j) Livro 10 - Perspectivas do Desenvolvimento Brasileiro.

k) Brasil em Desenvolvimento: Estado, Planejamento e Políticas Públicas

— edições 2009, 2010 e 2011.

1) Série Diálogos para o Desenvolvimento:

- Volume 1 - Diálogos para o Desenvolvimento.

- Volume 2 - A experiência do Conselho de Desenvolvimento Econômico e Social sob o governo Lula.

- Volume 3 - Complexidade e Desenvolvimento.

- Volume 4 - A Reinvenção do Planejamento Governamental no Brasil.

- Volume 5 - Burocracia e Ocupação no Setor Público Brasileiro.

- Volume 6 - Gestão Pública e Desenvolvimento: Desafios e Perspectivas

- Volume 7 - Efetividade das Instituições Participativas no Brasil: Estratégias de Avaliação.

- Volume 8 - Federalismo à Brasileira: Questões para Discussão.

- Volume 9 - Gestão e Jurisdição: o Caso da Execução Fiscal da União.

Embora não esgotem o conjunto de atributos desejáveis de um ideal amplo de desenvolvimento para o país, estas dimensões certamente cobrem uma parte bastante grande do espectro que seria necessário para garantir níveis simultâneos e satisfatórios de soberania externa, inclusão social pelo trabalho qualificado e qualificante, produtividade sistêmica elevada e regionalmente bem distribuída, sustentabilidade ambiental e humana, equidade social e democracia civil e política ampla e qualificada.

Mas somente se esta vontade for coletivamente organizada é que terá alguma chance de sucesso. Daí a importância estratégica do Estado para induzir ou 
catalisar esta vontade em nível nacional. Não há porque esperar que algo deste tipo e desta dimensão seja obtido por obra das circunstâncias.

É bastante improvável que o simples realizar-se de vidas atomizadas consiga produzir, em nível coletivo, os atributos acima mencionados de forma simultânea e satisfatória para a garantia de condições de vida e de reprodução social justas e equilibradas.

Por outro lado, o Estado pode muito, mas não pode tudo. Ele não é como muitas vezes se supôs em teorias do Estado - um ente externo e coercitivo aos movimentos da sociedade e da economia, dotado de racionalidade única, instrumentos suficientes e capacidade plena de operação. É, sim, parte integrante e constituinte da própria sociedade e da economia, que precisa se relacionar com outros agentes nacionais e internacionais para construir ambientes favoráveis à implementação de suas ações. ${ }^{3}$ É, então, diante da constatação acima enunciada que se parte para a recuperação analítica de alguns pontos importantes para o debate atual sobre o Estado e o desenvolvimento brasileiros. Entende-se que a fragmentação dos interesses articulados em torno do Estado e a frouxidão das instituições burocráticas e processuais em termos da canalização e resolução dos conflitos limitam a autonomia efetiva das decisões estatais cruciais e fazem com que o Estado seja ao mesmo tempo o lócus de condensação e processamento das disputas por recursos estratégicos (financeiros, logísticos, humanos, etc.) e o agente decisório último por meio do qual, de fato, se materializam ou se viabilizam os projetos políticos dos grupos dominantes vencedores.

No texto que se segue levantam-se questões e apontam-se perspectivas que permitam proporcionar as condições necessárias para a retomada do debate sobre o papel que o Estado, o planejamento público governamental e as políticas públicas de corte federal devem e podem ocupar no cenário atual, como indutoras do desenvolvimento nacional.

\section{DESENVOLVIMENTO: REQUALIFICANDO E RESSIGNIFICANDO O CONCEITO E O DEBATE NO BRASIL 4}

Quais são, hoje, os qualificativos mais pertinentes à ideia de desenvolvimento, dos quais se possa fazer uso corrente para avançar na construção de um entendimento comum deste conceito?

3 Um detalhamento algo mais teórico desta discussão pode ser visto em Estado e Economia no Capitalismo, de Adam Przeworski (1995), ou através do artigo "Autonomia versus interesses: considerações sobre a natureza do Estado capitalista e suas possibilidades de ação”, de J. Celso Cardoso Jr. (2006).

4 O restante deste texto é uma versão modificada da Introdução escrita para o livro Brasil em Desenvolvimento: Estado, planejamento e políticas públicas, produção institucional do IPEA (2009) coordenada neste ano por J. Celso Cardoso Jr. 
Desde o final da segunda guerra mundial até aproximadamente o começo dos anos de 1970, a palavra "desenvolvimento" se confundia com o conceito "crescimento econômico", pois era entendido, fundamentalmente, como o processo pelo qual o sistema econômico criava e incorporava progresso técnico e ganhos de produtividade no nível, sobretudo, das firmas.

Entretanto, com a constatação de que projetos de industrialização, por si sós, haviam sido insuficientes para engendrar processos socialmente includentes, capazes de eliminar a pobreza estrutural e combater as desigualdades, foi-se buscando - teórica e politicamente - diferenciações entre crescimento e desenvolvimento, e ao mesmo tempo, a incorporação de qualificativos que pudessem dar conta das ausências ou lacunas para o conceito. No Brasil, um exemplo sintomático desse movimento foi a inclusão do "S" na sigla do BNDE, que passou então a se chamar Banco Nacional de Desenvolvimento Econômico e Social, em 1982, mais de três décadas após a sua fundação.

Esse estratagema melhorava, mas não resolvia totalmente o problema. Estavam ainda de fora do conceito de desenvolvimento outros qualificativos importantes, que desde aquela época, já cobravam passagem pelos crivos teóricos e políticos pertinentes. O mais patente desses qualificativos de então, no contexto brasileiro da década de 1970, referia-se à questão democrática: seria possível chamar de desenvolvimento, um processo de crescimento econômico sem democracia, ainda que, esta mesma, matizada à época tão somente pelos seus próprios qualificativos "democracia civil" e "democracia política"?

A incorporação de direitos civis e políticos, num contexto de crescimento com autoritarismo, passava a ser uma demanda social e um desafio político imensos para melhor qualificar o sentido do desenvolvimento brasileiro na década de 1970.

Mesmo isso, no entanto, não resolvia totalmente a questão, e veio, então, com todo vigor, no bojo do processo de redemocratização do país nos anos de 1980, um movimento dos mais importantes para a história republicana e civilizatória brasileira: o movimento de conquista e constitucionalização de direitos sociais, como condição tanto para melhor qualificar a incipiente democracia nacional, como o próprio sentido do desenvolvimento aqui praticado.

No entanto, a dimensão social da democracia e do desenvolvimento não está, ainda hoje, definitivamente inscrita no imaginário público brasileiro, sendo, portanto, um ponto de embate teórico e político ainda muito vivo no Brasil, motivo pelo qual talvez ainda se tenha, na estrutura organizacional de diversos níveis e áreas de governo (e mesmo em organizações privadas) o "social" como qualificativo explícito de reivindicação.

Além do "social", outras dimensões igualmente relevantes de qualificação do desenvolvimento estão já há algum tempo cobrando seus espaços no significado 
implícito do desenvolvimento, para uma inteligibilidade coletiva mais homogênea do conceito. Tratando-se, bem entendido, de um processo histórico e social mutável e condicionado, não é o caso, aqui, de buscar exaurir os inúmeros qualificativos que poderiam ainda ser alinhavados para conferir um entendimento totalizante ao conceito de desenvolvimento.

Por outro lado, é, sim, possível e necessário elencar algumas outras dimensões a compor, hoje no Brasil, o espectro de qualificativos indispensáveis para uma compreensão contemporânea, civilizada e civilizante do desenvolvimento. Estão todas elas ainda no plano das reivindicações teóricas, num estágio de maturação política ainda bastante incipiente, e muito distantes também do imaginário coletivo. Mas já se avizinham e frequentam os debates públicos e já interessam à classe política, aos governantes e aos cidadãos comuns.

Nem todas são questões exatamente novas, mas todas elas são igualmente urgentes. Sem pretender esgotá-las ou hierarquizá-las, é possível, no entanto, identificar algumas das mais relevantes, tais quais estão sendo discutidas no âmbito do Ipea, por meio do processo interno de planejamento estratégico acima aludido.

\section{3 | ESPAÇOS DE SOBERANIA}

Em primeiro lugar, num contexto de crescente internacionalização dos fluxos de bens, serviços, pessoas, símbolos e ideias pelo mundo, está posta para as nações a questão dos espaços possíveis e adequados de soberania (econômica, política, militar, cultural, etc.) em suas respectivas inserções e relações externas. Este tema é especialmente caro a qualquer projeto de desenvolvimento que se pretenda ou se vislumbre para o Brasil, devido, entre outras coisas, a suas dimensões territorial e populacional, suas riquezas naturais estratégicas, sua posição geopolítica e econômica na América Latina e suas pretensões recentes em âmbito global.

Esta importante dimensão de análise está, portanto, ordenada sob o entendimento analítico de que o movimento das forças de mercado, por si só, não é capaz de levar economias capitalistas a situações socialmente ótimas de emprego, geração e distribuição de renda. Ademais, em economias em desenvolvimento, como a brasileira, emergem problemas tais como altos patamares de desemprego e de precarização do trabalho, heterogeneidade estrutural, degradação ambiental, inflação e vulnerabilidade externa.

Daí que o pleno emprego dos fatores produtivos (como a terra, o capital, o trabalho e o conhecimento) se converte em interesse e objetivo coletivos, apenas possível por um manejo de políticas públicas que articule virtuosamente os diversos 
atores sociais em torno de projetos de desenvolvimento includentes, sustentáveis e soberanos.

Nessa perspectiva, uma nação, para entrar em rota sustentada de desenvolvimento, deve necessariamente dispor de autonomia elevada para decidir acerca de suas políticas internas e também daquelas que envolvem o relacionamento com outros países e povos do mundo. Para tanto, deve buscar independência e mobilidade econômica, financeira, política e cultural; ser capaz de fazer e refazer trajetórias, visando reverter processos antigos de inserção subordinada para assim desenhar sua própria história.

Em segundo lugar, no plano estritamente interno, outras questões igualmente relevantes se manifestam. Os temas que sempre estiveram no centro das discussões sobre o crescimento econômico ganham novos enfoques, demandando que sejam atualizados em seus próprios termos e frente às demais dimensões cruciais do desenvolvimento. Está-se falando dos aspectos propriamente (micro)econômicos do crescimento, ligados às esferas da produção (primária, secundária e terciária), da inovação e da competitividade sistêmica e dinâmica das firmas e do próprio país.

Claramente, não se trata mais de priorizar — frente a outras dimensões igualmente relevantes do desenvolvimento - estratégias ou políticas que representem ganhos de produtividade com vistas apenas (ou primordialmente) à apropriação e acumulação empresarial (seja de controle privado ou estatal, seja ao nível individual ou setorial das firmas). Ao contrário, tem-sejá compreensão-mais teórica que política,ébem verdade - de que ganhos sistêmicos e dinâmicos de produtividade só podem ser obtidos (e só fazem sentido nesta nova conceituação de desenvolvimento que se busca construir), se as respectivas políticas ou estratégias de produção, inovação e competitividade estiverem concebidas e relacionadas à satisfação também das condições postas pelas dimensões da soberania externa, da coerência macroeconômica, da regulação pública (no sentido de estatal, institucional e democrática), da sustentabilidade ambiental, da convergência regional, do equilíbrio campo/cidade, da inclusão e sustentação humana e social, dentre outras dimensões e qualificativos a se explicitarem.

Em outras palavras, as atividades de ciência, tecnologia e inovação, territorialmente articuladas, são concebidas como fundamentais para a redução das desigualdades e para o próprio desenvolvimento nacional.

Reforça-se a ideia de que as políticas de desenvolvimento produtivo e tecnológico precisam ser econômica, social e ambientalmente sustentáveis, além de aderentes às diferentes realidades regionais do país. É necessário que a agenda pública priorize políticas de fomento, incentivo e regulação em favor da articulação de atores e regiões. 
Desta maneira, a compreensão de que políticas e estratégias para a estruturação de um Sistema Nacional de Inovação devem ser regionalmente articuladas e integradas faz com que temáticas ligadas à territorialização e regionalização do desenvolvimento adquiram centralidade na agenda pública. Por isso, esta dimensão do desenvolvimento pensa na estrutura produtiva e tecnológica, na inovação e na competitividade, como condicionantes de trajetórias de desenvolvimento que enfrentem as desigualdades regionais existentes no país.

Em terceiro lugar, portanto, está a compreensão de que temáticas ligadas à territorialização e regionalização do desenvolvimento tenham maior centralidade na agenda produtiva. Aqui é abordada gama ampla de velhas e novas questões que se fazem repercutir sobre as perspectivas do desenvolvimento nacional hoje, diante dos riscos crescentes ligados à fragmentação regional brasileira, com suas implicações diretas e indiretas sobre os espaços urbanos e sobre a sustentabilidade ambiental.

A redução de desigualdades entre os diferentes espaços territoriais do país, de um lado, e a configuração minimamente planejada das cidades e de sua infraestrutura social, com complementaridade entre habitação, saneamento e transporte público, de outro, são algumas das questões discutidas. A elas agregam-se os temas da redução dos impactos ambientalmente degradantes da atividade econômica e da regulação do avanço sobre o território em busca de suas riquezas, os quais se apresentam como igualmente desafiadores para o país.

Dito de outro modo, algumas das questões diretamente relacionadas às dimensões regional, urbana e ambiental são abordadas por meio de ideias que entendem ser a redução de desigualdades espaciais, a complementação, em espaços urbanos, dos componentes sociais da infraestrutura (habitação, saneamento e transporte público), e a concomitante redução de impactos ambientais em diversas ordens, imperativos categóricos do desenvolvimento.

Adicionalmente, a adequação e a logística de base da infraestrutura propriamente econômica é outra dimensão fundamental do desenvolvimento, mas que necessita estar permeada e orientada pelas dimensões do regional, do urbano e do ambiental, acima enunciadas. Assim, ganham destaque: a discussão sobre atualização da matriz energética brasileira, com ênfase em fontes renováveis e segurança energética; e a discussão sobre revisão, expansão e integração adequadas das infraestruturas de telecomunicações e de transportes, considerada esta última em todos os modais pertinentes ao Brasil. O desenvolvimento nacional depende, portanto, também de infraestrutura econômica, social e urbana - tudo em perspectiva conecta - e de arranjos institucionais capazes de satisfazer e compatibilizar, em conjunto, os reclamos por crescimento econômico, equidade social e sustentabilidade ambiental.

Não é por outra razão, então, que sustentabilidade ambiental é aqui afirmada como dimensão transversal inseparável das demais (social e econômica), 
devendo os ativos ambientais serem preservados, geridos e recuperados de forma harmônica e complementar àquelas. As políticas públicas devem dispensar especial atenção na criação de oportunidades para populações tradicionais e grupos socioambientalmente mais vulneráveis.

O acesso à água potável e a condições sanitárias adequadas são ativos fundamentais na concepção de desenvolvimento que já se faz imperativa entre os povos do mundo. A conservação das bacias hidrográficas, portanto, deve ser compatibilizada com as atividades econômicas em geral e com os processos em curso de urbanização no mundo.

A gestão dos biomas, da biodiversidade e da biotecnologia brasileira representa aspecto econômico e político essencial ao desenvolvimento do país, motivo pelo qual este deve ser pensado a partir de uma realidade de recursos naturais exauríveis.

As mudanças climáticas e o fenômeno do aquecimento global devem receber atenção especial e tratamento prospectivo para que se conheçam seus efeitos sobre os biomas e sobre a própria humanidade, e para que se formulem políticas preventivas em tempo hábil. Um novo modelo de desenvolvimento, enfim, deve incorporar inovações sociais, institucionais e tecnológicas que conduzam ao uso estratégico e sustentável desses ativos, traduzido no aumento da eficiência produtiva, no reaproveitamento de rejeitos e no estabelecimento de padrões de produção e consumo que respeitem as capacidades do ambiente.

Finalmente, há uma quarta questão de extrema relevância na discussão sobre o desenvolvimento: garantir direitos, promover a proteção social e gerar oportunidades de inclusão são não apenas objetivos plausíveis, mas também condições necessárias a qualquer projeto nacional. Visto este movimento em perspectiva histórica, percebe-se que a civilização ocidental constituiu um conjunto de parâmetros fundamentais de convívio e sociabilidade em torno dos quais passaram a se organizar certos direitos civis, políticos e sociais, balizadores da condição humana moderna. Condensados na ideia forte de cidadania, o acesso a este conjunto de direitos passa a operar como critério de demarcação para a inclusão ou exclusão populacional em cada país ou região, portanto, como critério adicional de demarcação para se aferir o grau de desenvolvimento nacional em cada caso concreto.

Estes temas são, por sua vez, aqui incorporados segundo a compreensão do Estado como ator estratégico fundamental em qualquer processo que se queira de desenvolvimento, pois é este ente, em última instância, o responsável por garantir a segurança interna, por ordenar o uso sustentável do território, por regular, enfim, a atividade econômica e promover políticas públicas.

Entende-se que, por mais que as economias e alguns processos sociopolíticos estejam internacionalizados, importantes dimensões da vida social 
permanecem sob custódia das políticas nacionais, afiançando a ideia de que o Estado é ainda a principal referência no que se refere à regulação de diversas dinâmicas sociais que se desenrolam em seu espaço territorial. Em suma, cidadania, inclusão e proteção social são elementos constitutivos cruciais para estratégias e trajetórias de desenvolvimento com maior equidade. A expansão e a consolidação dos direitos civis, políticos e sociais, reunidos sob a ideia de cidadania, devem, portanto, orientar o planejamento, a implementação e a avaliação das políticas públicas em geral. Este processo requer participação e engajamento do poder público, em todas as suas esferas e dimensões, bem como da sociedade civil e dos setores produtivos.

Isto tudo posto, percebe-se, portanto, que as dimensões de análise acima apresentadas como qualificativos hoje inescapáveis da moderna concepção de desenvolvimento visam conferir um sentido agregado ao esforço institucional que está em curso no Ipea.

\section{4 | ESTADO E PLANEJAMENTO GOVERNAMENTAL}

Este sentido agregado de que se fala, é um processo em construção, necessariamente contínuo, cumulativo e coletivo. O esforço de reflexão aqui realizado visa, portanto, institucionalizar e sistematizar, uma prática de acompanhamento, análise, avaliação e prospecção das diversas políticas, programas e ações governamentais de âmbito, sobretudo, federal. Com isso, pretende-se obter, ao longo dos anos, capacitação técnica e visão institucional abrangente e aprofundada acerca dos problemas nacionais e da capacidade das políticas públicas de enfrentálos adequadamente. Adicionalmente, espera-se, como resultado desta estratégia institucional, um incremento analítico gradual no que se refere a uma compreensão coletiva teoricamente mais inter-relacional dos diversos temas e assuntos em pauta, como também metodologicamente mais transdisciplinar em termos de técnicas e alternativas de pesquisa.

E, embora o objetivo declarado seja - como explorado até aqui identificar e construir, teórica e politicamente, os qualificativos do desenvolvimento, tais que deles se possa fazer uso corrente, para melhor caracterizar e simbolizar um entendimento coletivo comum do termo e do conceito, sabe-se que, do ponto de vista do Ipea, esta tarefa passa, necessariamente, pelo estudo do Estado, do planejamento e das políticas públicas, como instâncias inescapáveis de mediação entre os tais qualificativos até aqui sugeridos para uma nova compreensão de desenvolvimento, e o próprio desenvolvimento como projeto político em construção.

Realizar este esforço de maneira ordenada e sistemática é, portanto, algo que busca gerar acúmulo de conhecimento e massa crítica qualificada para um 
debate público bastante caro e cada vez mais urgente às diversas instâncias e níveis de governo no Brasil (e ao próprio Ipea em particular), no sentido de responder a questões do seguinte tipo:

- Em que consiste a prática de planejamento governamental hoje e que características e funções deveria possuir, frente à complexidade dos problemas, das demandas e necessidades da sociedade?

- Quais as possibilidades de redesenho e revalorização da função planejamento governamental hoje?

- Quais as características (atualmente existentes e aquelas desejáveis) e quais as possibilidades (atualmente existentes e aquelas desejáveis) das instituições de Governo e de Estado pensadas ou formatadas para a atividade de planejamento público?

- Quais os instrumentais e técnicas existentes (e quiçá aqueles necessários ou desejáveis) para as atividades de planejamento governamental condizentes com a complexidade dos problemas, das demandas e necessidades da sociedade?

- Que balanço se pode fazer das políticas públicas nacionais mais importantes em operação no país hoje?

- Que diretrizes se pode oferecer para o redesenho (quando for o caso) dessas políticas públicas federais, nesta era de reconstrução dos Estados nacionais, e como implementá-las?

\section{5 | PLANEJAMENTO: REQUALIFICANDO E RESSIGNIFICANDO O CONCEITO E O DEBATE NO BRASIL 5}

A atividade de planejamento governamental hoje não deve ser desempenhada como outrora, de forma centralizada e com viés essencialmente normativo. Em primeiro lugar, há a evidente questão de que, em contextos democráticos, o planejamento não pode ser nem concebido nem executado de forma externa e coercitiva aos diversos interesses, atores e arenas sociopolíticas em disputa no cotidiano. Não há, como talvez tenha havido no passado, um "cumpra-se" que se

5 O restante deste texto é uma versão modificada da Introdução escrita para o livro Brasil em Desenvolvimento: Estado, planejamento e políticas públicas, produção institucional do IPEA (2009) coordenada neste ano por J. Celso Cardoso Jr. 
realiza automaticamente de cima para baixo pelas cadeias hierárquicas do Estado, até chegar aos espaços da sociedade e da economia.

Em segundo lugar, com a multiplicação e complexificação das questões em pauta nas sociedades contemporâneas hoje, ao mesmo tempo que com a aparente sofisticação e tecnificação dos métodos e procedimentos de análise, houve uma tendência geral, também observada no Brasil, sobretudo após a Constituição de 1988, de pulverizar e de reduzir, por meio de processos não lineares nem necessariamente equilibrados de institucionalização de funções típicas e estratégicas ao nível do Estado, o raio de discricionariedade (ou de gestão política) da ação estatal, portanto, de planejamento no sentido forte do termo, de algo que precede e condiciona a ação.

Em outras palavras, pode-se dizer que, no Brasil, a o longo das duas últimas décadas, em paralelo à decadência da função planejamento governamental em geral, num ambiente ideologicamente hostil à presença e atuação do Estado, esta função pública foi adquirindo feições muito diferentes daquelas com as quais, no passado, ela costumava geralmente se identificar.

Hoje, na estrutura e forma de funcionamento do planejamento governamental operante no país, esta função está, em grande medida, esvaziada de conteúdo político, robustecida de ingredientes técnico-operacionais e de controle e comando físico-financeiros de ações difusas, diluídas pelos diversos níveis e instâncias de governo, cujo sentido de conjunto e movimento, se houver, mesmo setorialmente considerado, não é nem fácil nem rápido de identificar.

Então, se as impressões gerais, logo acima apontadas, sobre a natureza e algumas características gerais do planejamento governamental hoje estiverem corretas, ganha sentido teoricamente diferenciado e politicamente importante uma busca orientada a dar resposta às questões aqui suscitadas. Afinal, se planejamento governamental e políticas públicas são instâncias lógicas de mediação prática entre Estado e Desenvolvimento, então não é assunto menor ressignificar e requalificar — tal qual sugerido acima para a própria categoria “desenvolvimento" — os próprios termos pelos quais, atualmente, deve ser redefinido o conceito de planejamento público governamental.

Tal qual no caso da categoria desenvolvimento, também aqui é preciso um esforço teórico e político de grande fôlego para resignificar e requalificar o sentido de inteligibilidade comum ao termo/conceito de planejamento.

E tal qual como no caso da categoria desenvolvimento, também aqui não se pode fazer isso sem um trabalho cotidiano de pesquisa, investigação e experimentação, portanto, sem as perspectivas de continuidade e de cumulatividade, por meio das quais, ao longo do tempo, se consiga ir dando novo sentido - teórico e político - a ambos os conceitos. 
Ao se caminhar nesta direção, espera-se a obtenção de maior maturidade e profundidade para ideias ainda hoje não muito claras, nem teórica nem politicamente, para esta tarefa de redefinição e ressignificação do planejamento público governamental. Dentre tais ideias, quatro binômios aparecem com força no bojo desta discussão.

Em primeiro lugar, o binômio "planejamento - engajamento", isto é, a ideia de que, hoje, qualquer iniciativa ou atividade de planejamento governamental que se pretenda eficaz, precisa aceitar (e mesmo contar com) certo nível de engajamento público dos atores diretamente envolvidos com a questão, sejam atores da burocracia estatal, políticos e acadêmicos, sejam os próprios beneficiários da ação que se pretende realizar. Em outras palavras, a atividade de planejamento deve prever uma dose não desprezível de horizontalismo em sua concepção, vale dizer, de participação direta e envolvimento prático (sempre que possível) de todos os atores pertencentes à arena em questão.

Em segundo lugar, o binômio "articulação - coordenação", ou seja, a ideia de que grande parte das novas funções que qualquer atividade ou iniciativa de planejamento governamental deve assumir está ligada, de um lado, a um esforço grande e muito complexo de articulação institucional e, de outro lado, a um esforço igualmente grande - mas possível — de coordenação geral das ações de planejamento.

O trabalho de articulação institucional a que se refere é necessariamente complexo porque, em qualquer caso, deve envolver muitos atores, cada qual com seu pacote de interesses diversos, e cada qual com recursos diferenciados de poder, de modo que grande parte das chances de sucesso do planejamento governamental hoje depende, na verdade, da capacidade que políticos e gestores públicos tenham de realizar a contento este esforço de articulação institucional em diversos níveis. Por sua vez, exige-se em paralelo um trabalho igualmente grande e complexo de coordenação geral das ações e iniciativas de planejamento, mas que, neste caso, embora não desprezível em termos de esforço e dedicação institucional, é algo que soa factível ao Estado realizar.

Em terceiro lugar, o binômio "prospectivo-propositivo", vale dizer, a ideia de que, cada vez mais, ambas as dimensões aludidas - a prospecção e a proposição - devem compor o norte das atividades e iniciativas de planejamento público na atualidade. Trata-se, fundamentalmente, de dotar o planejamento de instrumentos e técnicas de apreensão e interpretação de cenários e de tendências, ao mesmo tempo de teor propositivo para reorientar e redirecionar, quando pertinente, as políticas, programas e ações de governo.

Em quarto lugar, o binômio "estratégias-trajetórias", que significa, claramente, dotar a função planejamento do poder de ser, ao mesmo tempo, o aglutinador de propostas, diretrizes, projetos, enfim, estratégias de ação, tais que 
anunciem, em seus conteúdos, as potencialidades implícitas e explícitas, vale dizer, as trajetórias possíveis e/ou desejáveis para a ação ordenada e planejada do Estado, em busca do desenvolvimento nacional.

O debate e o enfrentamento de todas as questões aqui enunciadas seguramente requerem a participação e o engajamento dos mais variados segmentos da sociedade brasileira, aí incluídos os setores produtivos e os movimentos organizados da sociedade civil. É fundamental, contudo, reconhecer que o Estado brasileiro desempenha um papel essencial e indelegável como forma institucional ativa no processo de desenvolvimento do país.

As questões agora postas visam exatamente a contribuir para lançar luz sobre a atuação do poder público na experiência brasileira recente, enfocando aspectos que instrumentalizem o debate sobre os avanços alcançados e os desafios ainda pendentes para uma contribuição efetiva do Estado ao desenvolvimento brasileiro.

Em suma, o desenvolvimento que se busca passa a ser, então, um processo contínuo de aprendizagem e conquistas, cujas dimensões ou qualificativos se agregam — teórica e politicamente - tanto simultaneamente como em patamares equivalentes de importância estratégica, pois hoje, finalmente, sabe-se que ou é assim, ou não se está falando de desenvolvimento.

A próxima seção detalhará os eixos para o desenvolvimento adotados pelo IPEA, na forma como se organizaram e se nomearam os livros da série Perspectivas do Desenvolvimento Brasileiro6.

\section{6 | EIXO INSERÇÃO INTERNACIONAL SOBERANA}

Uma nação, para entrar em rota sustentada de desenvolvimento, deve necessariamente dispor de autonomia elevada para decidir acerca de suas políticas internas e também daquelas que envolvem o relacionamento com outros países e povos do mundo. Para tanto, deve buscar independência e mobilidade econômica, financeira, política e cultural; ser capaz de fazer e refazer trajetórias, visando reverter processos antigos de inserção subordinada e desenhar sua própria história.

Os temas sobre política externa procuram discutir questões relacionadas às várias dimensões da ação internacional do país. Oferecem amplo quadro analítico

6 Para este debate, tal qual propagado pelo IPEA ao longo do triênio 2008-2010, ver em especial a série de 15 volumes publicados no âmbito do Projeto Perspectivas do Desenvolvimento Brasileiro e disponíveis em $\leq$ www. ipea.gov.br>. Posteriormente, dois livros-sínteses do referido projeto foram produzidos, sob coordenação e organização de CARDOSO JR. (2011; 2013). 
das questões que influenciam a presença do Brasil no mundo, como as tendências da geopolítica mundial, a participação do país nos acordos bilaterais e multilaterais e nos vários fóruns mundiais, seu papel na integração sul-americana, sua relação com os Estados Unidos, a participação em missão de paz da Organização das Nações Unidas (ONU), entre outros.

Os temas de economia internacional procuram discutir questões econômicas relevantes relacionadas à inserção internacional brasileira no período recente, proporcionando um amplo quadro descritivo e analítico das questões que influenciam a presença do Brasil no mundo: crise e regulação financeira internacional, sistema monetário-financeiro internacional, relação Estados Unidos-China, comércio internacional, integração sul-americana e investimento externo direto. A ideia central que fundamenta essa tarefa é a construção de uma agenda de pesquisa e de proposições de políticas a partir das reflexões oferecidas por esses trabalhos (IPEA, 2010a).

As perguntas que norteiam a reflexão abrangem:

- Que elementos considerar na construção de uma estratégia de inserção internacional soberana? Para que fins e em que medida o Brasil deve aceitar concessões de soberania? As dimensões de análise consideram: geopolítica, arranjo macroeconômico interno, perfil atual e almejado da estrutura produtiva brasileira, política de segurança, defesa nacional e questões ambientais. Instituições responsáveis pela inserção internacional brasileira: perfil, capacidade e funções. Diagnósticos e Propostas.

- Quais os determinantes e impactos dos investimentos diretos no país e os investimentos brasileiros no exterior? As dimensões de análise consideram: greenfield, fusões e aquisições, fluxos financeiros, propriedade intelectual, conhecimentos tradicionais, repartição de benefícios da biodiversidade.

- Como as políticas públicas podem atuar para aperfeiçoar a internacionalização das empresas brasileiras?

- Quais os efeitos da transferência e de difusão de tecnologia e do Investimento Direto Externo (IDE)? Exportação, instalação de empresas no exterior.

- Quais as políticas adequadas à transferência e difusão de tecnologia e do IDE? Estratégias dos grandes grupos empresariais internacionais, a inserção brasileira nestas estratégias e a articulação de políticas públicas para atração de investimentos. 
- Como difundir, acompanhar e avaliar os acordos de cooperação e integração? As dimensões de análise consideram: troca de conhecimento, marcos regulatório das relações de trabalho, fluxos migratórios, política de segurança nacional, defesa nacional, propriedade intelectual, recursos naturais, conhecimentos tradicionais, sustentabilidade ambiental e direitos humanos.

- Blocos regionais: perspectivas. Quais as perspectivas da Cooperação Sul-Sul?

- Qual deve ser a estratégia comercial brasileira?

- Quais são os determinantes estruturais das importações e das exportações brasileira? Que padrão de comércio internacional pode garantir independência tecnológica?

- Quais são os impactos da política macroeconômica sobre a estratégia comercial brasileira?

- Como as questões socioambientais afetam o fluxo comercial brasileiro? Análise da política comercial brasileira na Rodada Doha.

- Qual deve ser a estratégia do país como potencial grande exportador de petróleo?

- Qual deve ser a estratégia brasileira diante da concorrência asiática, em particular a China e a Índia?

\section{7 | EIXO MACROECONOMIA PARA O DESENVOLVIMENTO: CRESCIMENTO, ESTABILIDADE E EMPREGO}

A trajetória das economias capitalistas ao longo do tempo é permeada por ciclos econômicos determinados tanto endogenamente quanto por fatores exógenos. Com essa instabilidade inerente ao seu funcionamento, as forças de mercado por si só podem gerar resultados socialmente indesejáveis como altas taxas de desemprego, inflação e má distribuição de renda. Em economias subdesenvolvidas, emergem outros problemas tais como subemprego, heterogeneidade estrutural e vulnerabilidade externa. Por meio do planejamento e da ação do Estado, as políticas macroeconômicas podem ser utilizadas como instrumento para enfrentar essas questões. Ademais, além de influenciarem no curto prazo, tais políticas podem afetar 
a trajetória de crescimento de longo prazo da renda e da produtividade, bem como promover transformações estruturais visando a superação do subdesenvolvimento. A coordenação das dimensões fiscal, monetária e cambial do regime de política macroeconômica é essencial para materializar modelo de desenvolvimento nacional includente e sustentável.

\subsection{Macroeconomia Comprometida para o Desenvolvimento}

As economias em desenvolvimento e subdesenvolvidas, portanto, apresentam obstáculos estruturais específicos às suas condições históricas associados a suas inserções periféricas no sistema econômico internacional. Alguns destes entraves, como vasto contingente de força de trabalho subempregado nos setores de subsistência, tendência ao desequilíbrio do balanço de pagamentos e profunda heterogeneidade entre setores produtivos, não poderiam ser superados sem a promoção de transformações estruturais. Nesse contexto, a política econômica expande seus objetivos para além de questões específicas e imediatas, bem como o escopo do manuseio dos instrumentos de política econômica, característicos das economias desenvolvidas.

A gestão da política macroeconômica em um país ainda em desenvolvimento, como o Brasil, deve, então, ser conduzida de maneira a se atingir dois objetivos. 0 primeiro é promover o crescimento econômico e fornecer condições para que este seja sustentado; isto envolve a adoção de políticas anticíclicas para atenuar os efeitos das flutuações econômicas na produção e no emprego, sem descuidar de outros aspectos igualmente importantes, como a estabilidade de preços e a ampliação da capacidade produtiva do país.

O segundo é buscar o desenvolvimento e, para atingi-lo, são necessários investimentos maciços (públicos e privados) ao longo do tempo em saúde, educação e infraestrutura para garantir o bem-estar de toda a população e a igualdade de oportunidades. E investimentos, também de largo vulto, em ciência e tecnologia, os quais, associados a políticas industriais e agrícolas, revertam-se em fatores de impulso e dinamismo para os setores produtivos. O mais importante desafio que se apresenta é, portanto, tentar conciliar esses dois objetivos de tal forma que a gestão da política macroeconômica não cerceie as possibilidades de desenvolvimento econômico e social (IPEA, 2010b).

As perguntas norteadoras para a reflexão dessas questões consistem em:

- Qual modelo de desenvolvimento pode atender melhor as necessidades da sociedade brasileira?

- Como se deu a construção histórica do atual modelo econômico brasileiro? 
- Como o estudo da diversidade internacional de modelos de desenvolvimento pode contribuir para a formulação de um modelo de desenvolvimento brasileiro?

- Quais as principais restrições para o crescimento econômico sustentado?

- Como aprimorar as instituições brasileiras para a promoção do desenvolvimento no país?

- De que forma e em que extensão a distribuição de renda, o crescimento econômico e a inflação afetam-se reciprocamente?

- Qual o papel dos mercados interno e externo na estratégia de desenvolvimento nacional?

- Quais as medidas necessárias para se reduzir a vulnerabilidade a crises cambiais/financeiras?

- Qual é a resposta ótima de política macroeconômica à mudança de preços relativos na economia internacional?

- De que forma as políticas macroeconômica deveriam ser conduzidas para reduzir o impacto negativo da crise internacional sobre a economia brasileira?

- Como reorganizar o sistema financeiro internacional de modo a reduzir as fontes de vulnerabilidade numa economia globalizada?

- Como gerir a economia do pré-sal?

- Como evitar a doença holandesa e conciliar a estratégia de desenvolvimento produtivamente diversificado com a abundância de um recurso natural?

- Qual o melhor modelo para explorar o petróleo (partilha, concessão ou regime misto) e se apropriar dessa renda?

- Qual a melhor modo de gerir os recursos: dimensão federativa e fundo soberano: riqueza para o futuro versus necessidades de curto prazo?

- Quais os fatores críticos para o Brasil crescer de forma sustentada a taxas mais elevadas? 
- Como coordenar as políticas macroeconômicas com as demais políticas públicas para incentivar o crescimento sustentável com distribuição de renda?

- Qual o impacto de diferentes regras fiscais (tributação e gasto) sobre crescimento e distribuição de renda?

- Qual a relação entre investimento público e transferências fiscais e o crescimento econômico de médio e longo prazo? Existência e superação dos eventuais limites ambientais para a taxa de crescimento.

\section{EIXO ESTRUTURA PRODUTIVA E TECNOLÓGICA AVANÇADA E REGIONALMENTE INTEGRADA}

O desenvolvimento nacional depende de infraestrutura econômica, social e urbana e de um arranjo institucional capaz de promovê-la. A eficiência econômica, a equidade social, a redução de impactos ambientais e a redução de desigualdades espaciais em suas diversas escalas devem nortear o processo de adequação destas infraestruturas. Assim, as políticas públicas devem ser voltadas para: a atualização da matriz energética com ênfase em fontes renováveis e segurança energética; a revisão da matriz de transporte, com redistribuição e integração modal; avaliação e monitoramento do modelo de telecomunicações; e a integração entre políticas de saneamento, habitação e mobilidade garantindo o direito à cidade.

\subsection{Desafios do Desenvolvimento Produtivo Brasileiro}

Os desdobramentos da política industrial ao longo dos próximos anos dependerão da forma como a sociedade brasileira venha a se posicionar neste debate, pois, ao contrário da política dos anos 1960 e 1970, quando as decisões do que e como fazer eram tomadas por um grupo de burocratas "de cima para baixo", as políticas industriais atuais na América Latina e no Brasil demandam participação da sociedade em sua concepção e implementação.

Se, por um lado, a maior participação social na definição do que venha ser a política industrial torna mais difícil a busca de consensos entre atores públicos e privados, atores estes que muitas vezes trabalham com horizontes distintos e objetivos diferentes, por outro lado, essa busca de consenso no desenho e na implementação das políticas industriais modernas tem o potencial de torná-las ações de Estado, em vez de simples políticas de governo, cujo horizonte de implementação se restringe ao ciclo eleitoral de quatro anos. 
É nesse novo paradigma de construção de políticas industriais consensuais que se coloca o debate. De que forma esse consenso é construído? Como acompanhar e avaliar os resultados dessas políticas? Qual o papel dos atores privados e públicos na formulação e na implementação dessa nova política industrial, que nasce de um intenso debate com a sociedade? Quais os riscos que ainda se apresentam para o Estado na promoção de setores econômicos? (IPEA, 2010c).

\subsection{Diagnósticos e Políticas de Redução das Desigualdades Regionais}

Uma das características mais marcantes do Brasil é a grande diversidade socioeconômica e cultural existente ao longo de seu território. Essa diversidade remonta ao início da organização da nação brasileira, diante de um processo de colonização que ocorre de formas muito distintas entre suas regiões. Ao mesmo tempo em que as pluralidades de culturas e de formações geográficas são fontes de riquezas e de inspiração para os brasileiros, as grandes diferenças socioeconômicas podem enfraquecer seu pacto federativo e seu desenvolvimento socioeconômico.

A compreensão do padrão e da evolução das desigualdades regionais brasileiras tem sido então, há várias décadas, motivo de dedicação por grande número de formuladores de políticas, cientistas sociais, historiadores e artistas.

A partir da década de 1950 do século XX, o governo federal ampliou a execução de políticas de redução das desigualdades existentes entre as regiões brasileiras. Essas políticas, que estavam intimamente ligadas às de desenvolvimento nacional, se enfraqueceram a partir da década de 1980, momento em que a forte recessão, a desestabilização da economia e o grande endividamento do Estado reduziram sua capacidade de executar políticas regionais.

A desestruturação das políticas regionais aliada a fatos importantes como a abertura econômica e a reestruturação política do país modificou, a partir da década de 1990, de forma significativa, o padrão espacial das desigualdades socioeconômicas no país.

A atual realidade socioeconômica espacial que decorre dessas grandes transformações, a existência de uma literatura sobre economia regional mais rica, a maior disponibilidade de informações socioeconômicas que podem ser localizadas no espaço, bem como de metodologias utilizadas para o tratamento destas e o acúmulo de meio século de experiências relacionadas à execução de políticas regionais resultam em uma grande produção atual de análises sobre as desigualdades regionais brasileiras e as políticas regionais implementadas atualmente no Brasil e várias proposições para as políticas públicas (IPEA, 2010c). 
As perguntas norteadoras para esses questionamentos incluem:

- Como compatibilizar a agenda de investimentos prioritários de governos com o planejamento de longo prazo do Estado brasileiro? Compatibilização da execução dos planos de curto prazo e longo prazo. Papel da Gestão e administração da máquina pública. Arranjos jurídico-institucionais.

- Como o marco regulatório pode fornecer a segurança e os incentivos adequados para que investimentos em infraestrutura sejam realizados?

- Quais são as formas de financiamento que garantem os investimentos e sua continuidade?

- Quais elementos devem ser levados em conta na estruturação de uma política nacional de desenvolvimento territorial? Modelos de planejamento territorial e avaliação das práticas de planejamento urbano e regional. Como tornar os instrumentos de planejamento territoriais mais democráticos e mais efetivos?

- Como tratar a desarticulação entre os diversos instrumentos de política urbana e regional (Plano Diretor, Leis Orçamentárias, Planos Setoriais, etc.)? Desenho político-institucional e a articulação entre as diferentes políticas (PNOT, PNDU, ZEE, entre outros) e diferentes escalas (perspectiva interescalar). Ordenamento territorial e a rede urbana brasileira. Articulação institucional para a gestão metropolitana. A questão federativa e as diferenças territoriais. Redução das desigualdades regionais. A questão metropolitana. Articulação entre o planejamento territorial e as políticas setoriais.

- Qual a infraestrutura necessária para dar suporte ao desenvolvimento do país, considerando a política nacional de desenvolvimento territorial? Orientar o reordenamento territorial e infraestrutura econômica, social e urbana para uma rede urbana menos concentrada.

- Sistema de transporte integrado capaz de promover a mobilidade de pessoas e bens de forma mais acessível e eficiente. A regulação dos serviços públicos e o papel das agências reguladoras. Qual a relação entre infraestrutura, competitividade e custo Brasil? 
- A rede urbana e a infraestrutura econômica nacional frente à integração latino-americana.

- Como incorporar a questão ambiental ao planejamento sobre a infraestrutura socioeconômica e territorial do país?

- Que arranjos institucionais, políticos e econômicos podem garantir uma trajetória sustentável do nível de financiamento e investimento no desenvolvimento da infraestrutura?

- Como compartilhar os interesses da área privada e do governo na viabilização de investimentos em infraestrutura?

- Qual a importância da Constituição Federal de 1988 sobre o papel do financiamento e dos fundos setoriais?

- Como integrar as necessidades de expansão da infraestrutura com a sustentabilidade econômica (política macroeconômica, financiamento e investimento público / privado)?

- Como motivar o setor privado a investir em infraestrutura que equilibre interesses econômicos, sociais e ambientais?

- Quais são as lacunas sobre a regulamentação do financiamento dos setores de infraestrutura no ordenamento jurídico brasileiro?

- Que modelos de regulação, gestão e controle são mais adequados ao desenvolvimento da infraestrutura? Qual o modelo jurídico institucional adequado ao desenvolvimento da infraestrutura?

- Que tipos de papéis os agentes públicos e privados deverão desenvolver ao modelo de regulação?

- Qual a forma de atuação e o papel dos órgãos de controle? Quais os modelos e formas de atuação dos órgãos públicos de gestão?

- Como o sistema de avaliação de políticas públicas pode contribuir para sua formulação e aperfeiçoamento? 


\section{EIXO INFRAESTRUTURA ECONÔMICA NO BRASIL}

O desenvolvimento nacional depende de infraestrutura econômica, social e urbana e de um arranjo institucional capaz de promovê-la. A eficiência econômica, a equidade social, a redução de impactos ambientais e a redução de desigualdades espaciais em suas diversas escalas devem nortear o processo de adequação destas infraestruturas. Assim, as políticas públicas devem ser voltadas para: a atualização da matriz energética com ênfase em fontes renováveis e segurança energética; a revisão da matriz de transporte, com redistribuição e integração modal; avaliação e monitoramento do modelo de telecomunicações; e a integração entre políticas de saneamento, habitação e mobilidade garantindo o direito à cidade.

\section{1 | Diagnósticos e Perspectivas para 2025}

Não resta dúvida de que a oferta eficiente de serviços públicos de infraestrutura é um dos aspectos mais importantes das políticas de desenvolvimento econômico e social. A prestação eficiente de tais serviços condiciona significativamente a produtividade e a competitividade do sistema econômico, ao mesmo tempo em que melhora o bem-estar social. Portanto, uma adequada disponibilidade de infraestrutura e de seus serviços correlatos é condição indispensável para que o país possa desenvolver vantagens competitivas, alcançando maior grau de especialização produtiva.

Os investimentos em infraestrutura elevam a competitividade sistêmica da economia, melhorando as condições de transportes, de comunicação e de fornecimento de energia. Além disso, tais inversões promovem efeitos multiplicadores e dinamizadores nos demais setores, induzindo a outros investimentos.

Os investimentos em infraestrutura impactam na economia por meio de canais diretos - como a expansão da capacidade de abastecimento ou o escoamento da produção - e indiretos (a melhoria na produtividade total dos fatores), propiciando o desenvolvimento econômico e social da nação. A infraestrutura - quer promovida pelo Estado, quer pela iniciativa privada - tem o potencial de tornar mais rentáveis, e consequentemente mais atraentes, os investimentos produtivos, viabilizando maior eficiência ao sistema econômico (IPEA, 2010d).

Um dos pontos importantes a ser observado nos investimentos em infraestrutura é que seus impactos possuem características muito próprias e específicas para cada setor, de modo que não atuam de forma linear sobre o crescimento. De fato, cada setor apresenta uma capacidade e um formato na promoção do desenvolvimento, devendo ser observadas as necessidades e as potencialidades 
de cada região, a fim de planejar adequadamente as aplicações a serem realizadas (IPEA, 2010d).

\subsection{Subsídios para Uma Agenda de Pesquisa e Formulação de Políticas Públicas}

A infraestrutura econômica, social e urbana e o processo de desenvolvimento possuem elevado grau de correlação. A disponibilidade de infraestrutura no território constitui um indicador das suas condições de desenvolvimento. Ao mesmo tempo, essa disponibilidade ou sua ausência favorecem ou limitam o processo de desenvolvimento econômico e territorial.

Ao longo do processo de formação socioespacial, os investimentos em infraestrutura favorecem as condições de desenvolvimento socioeconômico de algumas porções do território, enquanto as ausências ou deficiências infraestruturais em algumas áreas restringem as suas possibilidades de desenvolvimento. Assim, a quantidade e a qualidade da infraestrutura disponível no território qualificam e condicionam seu processo de desenvolvimento.

Ao eleger a infraestrutura econômica, social e urbana como um dos eixos de desenvolvimento do país, o Ipea parte do entendimento que o desenvolvimento nacional depende da adequada provisão de infraestrutura econômica, social e urbana e, subsidiariamente, de um arranjo institucional capaz de promovê-la, seja em termos dos investimentos públicos ou privados necessários para dotar o país das infraestruturas necessárias, seja em termos de sua gestão e atualização,configurando um processo permanente que conforma uma política de Estado.

Enquanto política de Estado que deve favorecer o desenvolvimento do país, entende-se que o processo de adequação da infraestrutura econômica, social e urbana deve ser orientado pela promoção, concomitante, da eficiência econômica, da equidade social e da sustentabilidade ambiental, e pela diminuição das desigualdades espaciais, em suas diversas escalas.

Decorre disso o que pode ser qualificado como um dilema central relativo à infraestrutura: a implantação de determinadas infraestruturas mostra-se mais viável e atende a critérios, sobretudo de viabilidade econômico-financeira, em cidades e regiões que por sua posição hierárquica na rede urbana, por seu dinamismo e pelas funções que exercem no território já são mais bem dotadas em termos de infraestrutura, de modo que os investimentos em infraestrutura podem reforçar a sua concentração espacial e acentuar as disparidades socioespaciais. 
Além disso, os efeitos multiplicadores e virtuosos dos investimentos em infraestrutura tendem a dar melhor resposta em regiões que de alguma forma já são privilegiadas em termos de equipamentos e conhecimento, já exercem um papel importante em termos regionais e da rede de cidades e já atraem a maior (e melhor) parte dos investimentos públicos e privados (IPEA, 2010d).

\section{0 | EIXO SUSTENTABILIDADE AMBIENTAL NO BRASIL}

A sustentabilidade ambiental é afirmada como dimensão transversal inseparável das demais (social e econômica), devendo os ativos ambientais serem preservados, geridos e recuperados de forma harmônica e complementar a essas. As políticas públicas devem dispensar especial atenção na criação de oportunidades para populações tradicionais e grupos socioambientalmente mais vulneráveis. A gestão dos biomas e da biodiversidade brasileiras representa um aspecto econômico e político essencial na inserção internacional soberana do país. Assim, o desenvolvimento do país deve ser pensado a partir de uma perspectiva de recursos naturais exauríveis. Um novo modelo de desenvolvimento deve incorporar inovações sociais, institucionais e tecnológicas que conduzam ao uso estratégico e sustentável desses ativos, traduzido no aumento da eficiência produtiva, no reaproveitamento de rejeitos e no estabelecimento de um padrão de consumo que respeite a capacidade suporte do ambiente.

\subsection{Biodiversidade, Economia e Bem-estar humano}

A extraordinária multiplicação da espécie humana, aliada a uma não menos acentuada elevação nos padrões de consumo, com todas as consequências imagináveis sobre o ritmo de exploração dos recursos naturais, fez com que, na atualidade, a preocupação com a forma de inserção do homem na produção de sua existência e no entorno natural não possa mais ser esquecida quando se discute o processo de desenvolvimento econômico e social.

A integração da sustentabilidade ambiental no contexto econômico não é tarefa fácil. Por muito tempo, restrições dessa ordem não foram levadas a sério, não só no país. Vista como mais um empecilho ao dinamismo econômico que se desejava imprimir, sendo que a ânsia por taxas de crescimento cada vez maiores é tomada como um fim em si mesmo, a preocupação de caráter ambiental necessita, ainda, de alicerces mais sólidos para constituir-se como campo que possa opinar e orientar de forma autônoma decisões de políticas públicas, econômicas e sociais. Por outro lado, é campo marcado por profunda e seminal transdisciplinariedade. 
A humanidade encontra-se em um período de grandes desafios. O aumento de bem-estar, proporcionado pelo vigoroso crescimento econômico mundial ocorrido no século XX, é ameaçado por alterações ambientais ocorridas, em grande parte, pelas externalidades das próprias ações humanas.

O momento exige imediata atenção, pois são vigorosas as transformações a enfrentarem-se neste século. Neste contexto, esse estudo analisa as relações entre o desenvolvimento econômico e a sustentabilidade ambiental (IPEA, 2010e).

Como perguntas norteadoras, destacam-se:

- Que fatores afetam o meio ambiente do país?

- Quais os impactos de fatores sociais, como a desigualdade e a pobreza?

- Quais os impactos da urbanização? Qual o estado do saneamento ambiental no país?

- Quais as políticas para incentivar a redução do consumo, a reciclagem e o reaproveitamento e a disposição final adequada dos materiais? Como acontece a gestão de recursos hídricos?

- Manutenção da qualidade do ar e suas conexões com transporte e habitação

- Quais os impactos da ação das atividades produtivas?

- Quais os impactos das obras de infraestrutura? Quais os impactos do consumo e da produção de energia?

- Quais as alternativas de fontes energéticas renováveis para a melhoria da qualidade ambiental no Brasil? Quais os impactos do atual padrão de consumo?

- Quais as relações entre o uso do solo, a regularização fundiária, o planejamento territorial (ex. ZEE), o desenvolvimento regional e a qualidade ambiental?

- Como avaliar e mensurar a sustentabilidade ambiental nas diferentes regiões do Brasil?

- Quais as contribuições brasileiras para as mudanças climáticas e quais seus efeitos para o país?

- Quais as relações entre os diferentes setores produtivos e as mudanças climáticas? 
- Como reduzir as contribuições brasileiras para as mudanças climáticas, globais e regionais?

- Como reduzir as emissões de gases de efeito estufa nos diversos setores?

- Quais os principais efeitos das mudanças climáticas no Brasil?

- Como se adaptar às mudanças climáticas e mitigar seus efeitos com especial atenção às populações mais vulneráveis?

- Quais as características e potenciais de melhoria das políticas, da gestão e do planejamento ambientais no Brasil? Avaliar a ação do Estado. Redefinir competências e responsabilidades dos entes federativos.

- Como tornar efetiva a legislação? Como conciliar sustentabilidade ambiental e políticas sociais e setoriais?

- Comoincorporara sustentabilidadeambientalna contabilidade nacional?

- Como incorporar os custos e benefícios ambientais das atividades econômicas nas contas nacionais?

- Como incorporar as perdas ambientais nas contas nacionais?

- Quais são as vocações, potencialidades e fragilidades dos biomas brasileiros?

- Quais os fatores econômicos, sociais e políticos que ameaçam os biomas brasileiros?

- Quais os métodos apropriados de valoração econômica para o uso dos recursos naturais e quando a valoração é adequada para se internalizar as questões ambientais?

- Como aproveitar as potencialidades do uso econômico da biodiversidade compartilhando os benefícios com as populações tradicionais?

- Em que medida a produção e difusão do conhecimento (científico e tradicional) e a inovação no Brasil estão voltados para a compreensão e equacionamento do desenvolvimento sustentável?

- Quais as novas oportunidades para o uso estratégico dos ativos ambientais? 
- Quais são as implicações dos acordos e fóruns internacionais (ambientais ou não) sobre o desenvolvimento sustentável brasileiro?

- Como o Brasil recebe as agendas relativas à sustentabilidade no âmbito internacional?

- Como o Brasil pode/deve pautar as questões ambientais junto às Organizações Multilaterais?

\section{1 | EIXO PERSPECTIVAS DA POLÍTICA SOCIAL NO BRASIL}

Cidadania, inclusão e proteção social são elementos constitutivos fundamentais de uma estratégia de desenvolvimento com maior equidade. A expansão e a consolidação dos direitos civis políticos e sociais, reunidos sob a ideia de cidadania, devem orientar o planejamento, a implementação e a avaliação das políticas públicas. Este processo requer participação e engajamento do Poder Público, em todas as suas esferas, da Sociedade Civil e dos Setores Produtivos.

\section{1 | Perspectivas Abertas}

Antagônicas, antitéticas, antinômicas: eis algumas das qualificações utilizadas pela literatura para descrever as relações entre a regulação social e a dinâmica econômica, ao menos em sociedades que se organizam em torno de mercados. Em tais sociedades, definidas desde o início da era moderna como capitalistas, os mercados são os mecanismos fundamentais de direcionamento dos esforços humanos e dos recursos naturais disponíveis. Mecanismos que atuam à medida que podem se valer do livre confronto entre demanda e oferta de capitais, de terras, de produtos, de serviços, de trabalho e assim por diante. Desse confronto resulta um intrincado conjunto de preços, que sinalizam aos atores qual deve ser o sentido da dinâmica econômica, no que tange a cada uma das mercadorias citadas, no tempo presente ou mesmo futuro.

O mercado de trabalho, especificamente, sempre foi o palco dos maiores antagonismos entre a atuação dos atores público-estatais e dos atores privados nas sociedades capitalistas. As sucessivas tentativas de regulação do mercado laboral pelo Estado foram o resultado de antinomias várias entre trabalhadores e empresários, como atesta a longa história dos conflitos operários a partir da metade do século XIX. Em boa medida, essas tentativas de regulação versaram sobre a maneira pela qual a capacidade de trabalho seria convertida em uma mercadoria, stricto sensu. Ou seja, versaram sobre a própria constituição do mercado laboral, que é a disponibilização 
de pessoas livres para alienar sua potencialidade de trabalho a outrem, em troca de pagamento de uma contraprestação.

Enfim, a criação de direitos laborais - anteriormente referida como a juridificação do trabalho —, assim como de direitos sociais - juridificação do não trabalho - , foi uma resposta aos vários problemas gerados pelo movimento de mercantilização do trabalho nas sociedades capitalistas. Problemas de aguda assimetria política, social e econômica entre trabalhadores e empresários, que historicamente se manifestaram quase sempre em desfavor dos primeiros.

Mas é preciso ressaltar que essa criação de direitos, própria da esfera política, esteve em contradição permanente com a acumulação de capital, própria da esfera econômica. Daí a assertiva da literatura, de que as relações travadas entre a regulação social e a dinâmica econômica caracterizaram-se por serem antagônicas, antitéticas e antinômicas (IPEA, 2010f).

Entre outros aspectos, questiona-se até que ponto essa perspectiva da literatura dá conta da situação atual de países como o Brasil. Ou seja, até que ponto é adequada e suficiente tal perspectiva, dado que ela está preocupada essencialmente com as contradições entre a regulação social e a dinâmica econômica.

Esse questionamento surge a partir da constatação de que a política social, com seus diversos vetores e componentes definidos ao fim da década de 1980, influi sobremaneira na definição dos parâmetros vigentes da economia brasileira, de um ponto de vista macro, meso ou mesmo micro.

Como perguntas norteadoras, destacam-se:

- Quais são os elementos constitutivos e a abrangência da questão social no país?

- Como o Estado vê a questão social no discurso institucional e na agenda política?

- O que o Estado faz? Qual a prática institucional. O que a sociedade e os grupos organizados demandam?

- Qual modelo de desenvolvimento incorpora a proteção social como elemento fundamental?

- Como o Estado brasileiro pode promover e conciliar a equidade social e a eficiência econômica?

- Qual o Sistema de Proteção Social mais adequado ao Brasil?

- Em que medida o Sistema de Promoção Social Brasileiro é adequado ao conceito de cidadania estabelecido pela 
Constituição Federal de 1988? Quais os padrões de universalização e de focalização? Quais e como são os arranjos institucionais?

- Como as políticas de proteção social incidem de forma distinta sobre grupos definidos pelo cruzamento das seguintes dimensões: regional; gênero; raça; deficiências; fases da vida; renda, classe e riqueza.

- Quais concepções das dimensões definidas acima estão presentes nas políticas de proteção social e geração de oportunidades?

- Como distintas concepções de justiça influenciam as políticas de proteção social e geração de oportunidades?

- Como mudanças demográficas e socioeconômicas influem sobre novas demandas de proteção social?

- Qual o papel do Estado na geração das oportunidades?

- Como a proteção social pode contribuir para a geração de oportunidades?

- Quais as inter-relações entre as políticas públicas e a geração de oportunidade?

- Quais as formas de garantir autonomia familiar, ou individual, ao final de um tempo de vigência de um programa social?

- Como superar as linhas de pobreza e buscar a mobilidade social?

- Como aprimorar a administração pública para a adequada gestão da política social?

- Gestão de Recursos Humanos. Quantidade e qualidade dos Recursos Humanos. Transparência. Gestão da Informação.

- Como avaliar as políticas sociais? Princípios. Integralidade. Universalidade. Efetividade. Eficácia. Eficiência. Equidade. Dimensões de Análise. Impactos. Federalismo. Desenho. Processo. Resultados.

- Como avaliar o impacto de políticas sociais a partir do princípio de equidade? 
- Quais são as políticas mais eficazes de enfrentamento às desigualdades?

- Em que medida a cobertura do Sistema de Proteção Social impacta o processo de desenvolvimento?

\section{2 | EIXO FORTALECIMENTO DO ESTADO, DAS INSTITUIÇÕES E DA DEMOCRACIA}

Não existe experiência bem sucedida de desenvolvimento que tenha prescindido do Estado como ator estratégico nos processos nacionais de construção econômica, social e política. Paralelamente, por mais que as economias e alguns processos sociopolíticos estejam internacionalizados, importantes dimensões da vida social permanecem sob custódia das políticas nacionais, afiançando a ideia de que o Estado é ainda a principal referência no que se refere à regulação das diversas dinâmicas que se desenrolam em seu espaço territorial. Sendo assim, é imprescindível refletir sobre os arranjos institucionais mais adequados para conjugar Estado, mercado e sociedade em torno de um modelo de desenvolvimento includente, soberano e sustentável, que seja a meta da nação brasileira e o objetivo maior das políticas públicas.

\subsection{Estado, Instituições e Democracia - República}

O conceito de república não é unívoco e tem sido empregado no pensamento e na análise política para se referir a diferentes questões. Em termos bastante sintéticos, as duas acepções mais comumente relacionadas a esta ideia se referem, de um lado, a uma forma de governo instituída pela vontade da comunidade política - o que, no caso das experiências contemporâneas, se contrapõe aos governos monárquicos e se aproxima dos regimes democráticos - e, de outro, a uma forma de vida política fundada na primazia do interesse comum - que requer o engajamento da comunidade na condução da coisa pública e se faz expressar de maneira especial nos princípios, nas práticas e nos procedimentos que conformam as instituições.

Embora ambas as acepções não se oponham, e até se complementem, a discussão que se pretende fazer neste texto aborda a república a partir da segunda delas, interessando discutir especificamente o caráter republicano - ou não - das instituições constitutivas do Estado brasileiro, entendido enquanto agência primordial da comunidade política para gestão do que é público. 
E por que recolocar em debate o tema republicano? Primeiramente, porque se reconhece que se trata de referência importante na reflexão política atual. Nas últimas décadas, a república ressurgiu como referência importante nas reflexões sobre a política. Noções como virtude cívica, espaço público, bem comum, bom governo, comunidade política, "interesse bem compreendido", entre outras pertencentes à gramática da res publica, têm sido mobilizadas tanto para tematizar a sociabilidade corriqueira nos diferentes contextos de interação política, quanto para abordar a questão do desempenho e do aprimoramento do Estado e das instituições democráticas (IPEA, 2010, g).

\subsection{Estado, Instituições e Democracia — República}

Refletir sobre democracia em um contexto de discussão sobre perspectivas para o desenvolvimento brasileiro sugere uma aproximação até certo ponto original, tanto em nosso pensamento social quanto em nossa práxis política. A tarefa de construção de um projeto para o desenvolvimento de longo prazo, diante da qual o país mais uma vez se vê colocado, sempre teve foco em dois grandes temas: o crescimento econômico e a distribuição de renda. Os elementos políticos e institucionais que organizam as relações sociais e ajudam a promover um sentido comum de cidadania raramente tiveram espaço nessa agenda.

A democracia, em particular, só pôde entrar em cena como "possível resultante" do desenvolvimento, na ótica da teoria da modernização ou como um de seus "pressupostos abstratos", na visão mais recente de que, com a consolidação de instituições democráticas, já não se pode mais pensar o desenvolvimento nos mesmos termos e condições do período autoritário. Ao colocar a democracia no centro do debate sobre desenvolvimento, abre-se a possibilidades para reconsiderar essas relações e, no limite, reconhecer na democracia um elemento catalisador do desenvolvimento (IPEA, 2010, g).

\section{3| Estado, Instituições e Democracia - Desenvolvimento}

A primeira década do século XXI deixou evidentes as fraquezas do modelo de desenvolvimento liberal em proporcionar prosperidade econômica e equalização social no Brasil e na América Latina. Na verdade, o que se materializou, ao longo da década de 1990, foram problemas como vulnerabilidade nas contas externas e endividamento público em praticamente todos os países da região, bem como baixo crescimento econômico, deterioração dos principais indicadores do mercado de trabalho e degradação ambiental.

Com isso, esse modelo foi perdendo legitimidade, o que contribuiu, sobretudo a partir de 2002, para vitórias eleitorais de muitos governantes latino- 
americanos que adotaram, em maior ou menor grau, proposições de políticas do tipo nacional-popular ou neodesenvolvimentistas que haviam sido menosprezadas ao longo de praticamente 30 anos.

Acrescido a isto, mais recentemente, a própria crise internacional de 2008, originada nos Estados Unidos, suscitou questionamentos ao tipo de governança global em curso, já que esse país era o benchmark, por assim dizer, tanto da política econômica como das instituições e regras do jogo do modelo liberal. Por esses e outros motivos, é extremamente oportuna a retomada da discussão a respeito do papel do Estado, do planejamento e do desenvolvimento no Brasil e no mundo (IPEA, 2010, g).

As perguntas norteadoras consistem em:

- Que modelos de Estado melhor se adéquam aos desafios do desenvolvimento?

- Qual desenho de organização federativa: desigualdades, cooperação e financiamento?

- Qual organização estatal: relação entre poderes, suas funções e competências?

- Qual atualidade das narrativas clássicas sobre o Estado brasileiro (patrimonialismo, clientelismo, autoritarismo, corporativismos, cooptação etc.)

- Como aprimorar a administração pública?

- Qual a estrutura, os processos, as tecnologias de gestão, a cultura organizacional e qualificação profissional da burocracia?

- Responsividade, responsabilização, transparência e combate à corrupção.

- Como aprimorar os processos de definição de agenda, formulação, implementação, avaliação e controle das políticas públicas, tendo em vista a construção de um modelo de Estado que maximize a participação social?

- Qual a articulação entre os diversos programas e ações governamentais e a busca por eficácia, eficiência e efetividade na gestão de políticas públicas?

- Quais os modos de atuação da sociedade civil na construção e na implementação de políticas públicas e de um modelo de Estado mais democráticos? 
- Como aprimorar a democracia brasileira?

- Quais as alternativas para a configuração dos sistemas político e eleitoral?

- Quais instrumentos de participação social nos processos decisórios e quais as formas de articulação entre Estado e Sociedade Civil?

- Que elementos afetam a legitimidade da democracia e o grau de confiança nas instituições?

- Como aprimorar padrões da representação de interesses e da capacidade de o Legislativo tomar decisões mais bem informadas?

- Qual o papel das instituições da justiça e da segurança no aprofundamento da democracia brasileira?

\section{3 | COMPLEXIDADE E DESENVOLVIMENTO}

Percebe-se, então, que as dimensões de análise aqui apresentadas como qualificativos do desenvolvimento, hoje inseparáveis de uma concepção moderna deste conceito, visam a conferir um sentido agregado ao esforço de entendimento do desenvolvimento em perspectiva contemporânea e complexa. Esse sentido agregado de que se fala é um processo em construção, necessariamente contínuo, cumulativo e coletivo. O esforço de reflexão aqui realizado visa, também, a contribuir para uma prática de acompanhamento, análise, avaliação e prospecção das diversas políticas, programas e ações governamentais de cunho menos segmentado, comparado ao que se tem praticado, em linhas gerais.

Assim, poder-se-ia obter, ao longo dos anos, visão algo mais abrangente e aprofundada acerca dos problemas nacionais e da capacidade das políticas públicas de enfrentá-los de modo adequado. Adicionalmente, espera-se um incremento analítico gradual no que se refere a uma compreensão teórica mais inter-relacional dos diversos temas e assuntos em pauta, como também abordagem metodológica mais transdisciplinar em termos de técnicas e alternativas de pesquisa.

A sensação de viver em uma época em aceleração crescente, e de rápidas mudanças, reflete-se na limitação do vocabulário contemporâneo em nomear ou qualificar o tempo presente. Em contexto de generalizadas transformações experimentadas mundialmente desde a segunda metade do século XX, a face do Brasil atual também se transformou e se complexificou. Sua sociedade, os arranjos políticos 
e o tipo de Estado que aqui se construiu foram forjados na tensa relação entre os interesses políticos internos, suas disputas e embates, e as pressões internacionais.

Com isso, as incertezas sobre o presente e as dificuldades em nomeálo parecem apontar para uma transformação da cultura contemporânea, mais especificamente,uma transformação queatingiu em cheiosuas modalidades tradicionais de inteligibilidade. Mas além de sinalizar para a limitação da capacidade de nomear o presente, a crise de paradigmas da atualidade também aponta para a insuficiência das tradicionais abordagens compartimentadas e estritamente disciplinares diante da complexidade do nosso tempo. É neste sentido, portanto, que adquirem relevância os esforços de inter, multi e transdisciplinaridade como estratégias metodológicas para a capitalização dos saberes requeridos para o desenvolvimento que se agregam teórica e politicamente - tanto em simultâneo como em patamares equivalentes de importância estratégica, pois hoje, finalmente, sabe-se que ou é assim ou não se está falando de desenvolvimento. 


\section{4 | REFERÊNCIAS BIBLIOGRÁFICAS}

CARDOSO JR., J. C. Autonomia versus interesses: considerações sobre a natureza do Estado capitalista e suas possibilidades de ação. Campinas-SP: Leituras de Economia Política, revista dos estudantes de pós-graduação do Instituto de Economia da Unicamp, n. 12, 2006.

CARDOSO JR., J. C. \& SIQUEIRA, C. H. R. Introdução: A história como método e a centralidade do Estado para o desenvolvimento das nações. In: CARDOSO JR., J. C. (Org.). Desafios ao Desenvolvimento Brasileiro: contribuições do conselho de orientação do Ipea. Brasília-DF: Ipea, 2009.

CARDOSO JR. J. C. (Org). Para a Reconstrução do Desenvolvimento no Brasil: eixos estratégicos e diretrizes de política. São Paulo: Ed. Hucitec, 2011a.

CARDOSO JR. J. C. (Org). A Reinvenção do Planejamento Governamental no Brasil. Brasilia: Série Diálogos para o Desenvolvimento, volume 4, IPEA, 2011b.

CARDOSO Jr., J. C. (Org). República, Democracia e Desenvolvimento: contribuições para o Estado brasileiro contemporâneo. Brasília: IPEA, 2013 (no prelo).

CARDOSO JR., J. C., SANTOS, J. C. e ALENCAR, J. (Orgs). Diálogos para o Desenvolvimento: a experiência do CDES sob o governo Lula. Brasília: Série Diálogos para o Desenvolvimento, volume 2, IPEA, 2010.

CARDOSO JR., J. C.; SIQUEIRA, C. H. R. (Orgs). Complexidade e Desenvolvimento. Brasilia-DF: Série Diálogos para o Desenvolvimento, volume 3, IPEA, 2011.

GARCIA, R. C. Reorganização do Processo de Planejamento do Governo Federal: o PPA 20002003. Brasília: Texto para Discussão IPEA, n. 726, 2000.

IPEA. Brasil em Desenvolvimento: Estado, planejamento e políticas públicas. Brasília: IPEA, edição 2009.

IPEA. Brasil em Desenvolvimento: Estado, planejamento e políticas públicas. Brasília: IPEA, edição 2010.

IPEA. Brasil em Desenvolvimento: Estado, planejamento e políticas públicas. Brasília: IPEA, edição 2011.

IPEA (Instituto de Pesquisa Econômica Aplicada). Inserção Internacional Brasileira. Brasília: Projeto Perspectivas do Desenvolvimento Brasileiro, livro 3, volume 1 (Temas de Política Externa) e volume 2 (Temas de Economia Internacional), IPEA, 2010a.

IPEA (Instituto de Pesquisa Econômica Aplicada). Macroeconomia para o Desenvolvimento: crescimento, estabilidade e emprego. Brasília: Projeto Perspectivas do Desenvolvimento Brasileiro, livro 4, IPEA, $2010 b$.

IPEA (Instituto de Pesquisa Econômica Aplicada). Estrutura Produtiva Avançada e Regionalmente Integrada. Brasília: Projeto Perspectivas do Desenvolvimento Brasileiro, livro 5, volume 1 (Desafios do Desenvolvimento Produtivo Brasileiro) e volume 2 (Diagnóstico e Políticas de Redução das Desigualdades Regionais), IPEA, 2010c. 
IPEA (Instituto de Pesquisa Econômica Aplicada). Infraestrutura Econômica, Social e Urbana. Brasília: Projeto Perspectivas do Desenvolvimento Brasileiro, livro 6, volume 1 (Infraestrutura Econômica no Brasil : diagnósticos e perspectivas para 2025) e volume 2 (Infraestrutura Social e Urbana no Brasil: subsídios para uma agenda de pesquisa e formulação de políticas públicas), IPEA, 2010d.

IPEA (Instituto de Pesquisa Econômica Aplicada). Sustentabilidade Ambiental no Brasil: biodiversidade, economia e bem-estar humano. Brasília: Projeto Perspectivas do Desenvolvimento Brasileiro, livro 7, IPEA, 2010e.

IPEA (Instituto de Pesquisa Econômica Aplicada). Perspectivas da Política Social no Brasil. Brasília: Projeto Perspectivas do Desenvolvimento Brasileiro, livro 8, IPEA, 2010 .

IPEA (Instituto de Pesquisa Econômica Aplicada). Estado, Instituições e Democracia. Brasília: Projeto Perspectivas do Desenvolvimento Brasileiro, livro 9, volume 1 (República), volume 2 (Democracia) e volume 3 (Desenvolvimento), IPEA, 2010g.

PRZEWORSKY, A. Estado e Economia no Capitalismo. Rio de Janeiro: Relume-Dumará. 1995. 